\title{
Couple formation and spawning between two female Discus Fish (Symphysodon aequifasciatus - Cichlidae) in captivity
}

\author{
Douglas da Cruz MATTOS ${ }^{1 *}$, Rafaela SCRENCI-RIBEIRO², Leonardo Demier CARDOSO ${ }^{1}$, \\ Manuel Vazquez Vidal JUNIOR ${ }^{1}$ \\ 1 Universidade Estadual do Norte Fluminense Darcy Ribeiro, Laboratório de Zootecnia, Campos dos Goytacazes, RJ, Brasil. \\ 2 Universidade Estadual do Norte Fluminense Darcy Ribeiro, Setor de Estudos de Etologia, Reintrodução e Conservação de Animais Silvestres, Laboratório de Ciências \\ Ambientais, Campos dos Goytacazes, RJ, Brasil. \\ * Corresponding author: douglas_uenf@yahoo.com.br
}

\section{ABSTRACT}

In an experiment performed to characterize the reproductive behavior of the discus fish in captivity, couple formation with two females was observed. The observations were carried out in captivity, based on ad libitum methodology. Adult individuals were allowed to naturally form couples. The couple formation was considered when individuals performed the substrate cleaning behavior. Fifteen couples were selected. The eggs of three couples did not initiate embryonic development and became infeasible within three days after spawning. We found that these spawnings belonged to all-female couples. The sex of the individuals in same-sex couples was confirmed through subsequent couple formation and spawning of fertile eggs with known males. Eggs were deposited by one or both females in the same-sex couples. Double spawnings were larger and differentially colored. The motivations that lead individuals of the same sex to form couples in this species are still unknown.

KEYWORDS: reproduction, behavior, aquaculture, Amazonian fish

\section{Formação de casal e desova com duas fêmeas do acará disco (Symphysodon aequifasciatus - Cichlidae) em cativeiro}

\section{RESUMO}

Em um experimento realizado para caracterizar o comportamento reprodutivo de acarás disco em cativeiro, observou-se a formação de casais com duas fêmeas. As observaçôes foram realizadas em condiçôes ex situ, com base na metodologia ad libitum. Grupos de indivíduos adultos foram distribuídos em aquários para formação espontânea de casais. A formação de um casal foi considerada quando os indivíduos apresentaram o comportamento de limpeza do substrato. Quinze casais foram selecionados. Observamos que os ovos de três casais não iniciaram o desenvolvimento embrionário e se tornaram inviáveis entre o segundo e o terceiro dia após a desova. Verificou-se que eram casais constituídos por duas fêmeas. O sexo dos indivíduos desses três casais foi confirmado posteriormente por meio de acasalamento e produção de desovas viáveis com machos conhecidos. As desovas dos casais de mesmo sexo foram produzidas por uma ou as duas fêmeas. Desovas duplas tinham duas coloraçóes distintas e foram bem maiores que as de casais de machos e fêmeas. As motivaçôes que levam indivíduos de acará disco do mesmo sexo a formar casais ainda são desconhecidas.

PALAVRAS-CHAVE: reprodução, comportamento, aquicultura, peixe amazônico 
Neotropical cichlids destined to ornamental purposes have great commercial demand, but there is little relevant information about their development and reproduction (Dias and Chellappa 2003). Among the species of Neotropical cichlids sold for ornamental purposes, the discus fish, Symphysodon aequifasciatus Pellegrin, 1904, Cichlidae, which is native to the rivers of the Amazon basin in Brazil, Peru and Colombia (Wattley 1991), stands out. The main characteristics of this species are its small size, about $20 \mathrm{~cm}$ in length, high and rounded body shape, in addition to a wide range of colors.

Understanding the reproductive process is an essential part of the study of the biology of species (Silva and Esper 1991), and the reproduction of the discus fish in captivity is one of the biggest barriers to their commercial production. Symphysodon aequifasciatusis is a species of biparental care, characterized by maintaining adhesive eggs and the larvae on the substrate. Parental care is only ceased when the offspring reaches independence (Wattley 1991). In an experiment conducted to characterize the reproductive behavior of the discus fish in captivity, couple formation between two females was observed.

The observations were carried out in the aquaculture sector of Universidade Estadual do Norte Fluminense Darcy Ribeiro (UENF), from March 2009 to June 2010, based on the ad libitum methodology proposed by Altmann (1974). We selected 42 adult individuals from the stock of the aquaculture sector of UENF, with average values of $13.09 \pm 1.58 \mathrm{~cm}$ length, $10.39 \pm 0.98 \mathrm{~cm}$ height, and $62.15 \pm 1.73 \mathrm{~g}$ weight. They were distributed in seven experimental aquariums, totaling six fish per aquarium. Each aquarium had a capacity of $50 \mathrm{~L}$ working volume and was equipped with an aeration system, a foam filter for suspended solid retention, and 30$\mathrm{cm}$ plastic tube to serve as spawning substrate, given that this species spawns naturally on trunk surfaces. Since this species does not present apparent sexual dimorphism (Câmara 2004) we distributed six specimens per tank to the natural formation of couples. We considered that a couple was formed when the individuals cleaned the substrate, a characteristic behavior of different cichlid species in the moments prior to spawning. According to this criterion, 15 couples were selected.

After couple formation, spawning naturally occurred for the 15 couples, but it was observed that the eggs of three couples did not initiate embryonic development and became inviable between the second and third days after spawning. By analyzing the three couples that produced the inviable eggs, we found that they consisted of pairs of females, because we tested them with males later. These female couples displayed parental care with the spawn, performing aeration of the spawn with flipper movements and the removal of the first eggs that became inviable, both common behaviors of male/ female couples in this species (Mattos et al. 2016).
By comparing the spawns of male/female couples with those of the three same-sex couples, we observed that oocytes were released either by one or both females (Figure 1). Spawning by both females was evidenced by the disproportionate number of eggs in relation to the average number of eggs in male/female spawns. Also, the oocytes of the two different spawns differed in their color pattern: one spawn had a yellowish tone, while the other had an orange tone, showing clearly that they came from different individuals (Figure 1B).

After confirming the non-viability of their spawns, the six females of the same-sex couples were separated and each one was paired in individual aquariums with a male of confirmed gender and fertility. With the change of partners, it was observed that females paired with the new male partners and showed the normal reproductive behavior characteristic of the species and spawned normally. The spawns were viable and after egg-hatching, the couple showed normal parental care for the offspring (Mattos et al. 2016).

Previous studies on other species reported that the courtship of individuals of the same sex can occur in nonreproductive individuals, but the causes that lead to such behavior are still unknown. This was not the case with our same-sex couples of $S$. aequifasciatus, since the females generated viable offspring when paired with males.

Bailey and Zuk (2009) listed 14 species from different taxonomic groups (mammals, birds, insects and reptiles) that presented homosexual behavior in the wild and in the laboratory, performing courtship, pair bonding and copulation. For fish, information on reproductive behavior of same-sex couples is scarce.

Attraction behavior among individuals of the same sex was also observed in males of guppy, Poecilia reticulate Peters, 1859, where male individuals kept in aquariums only with others of the same sex had higher courtship behavior when
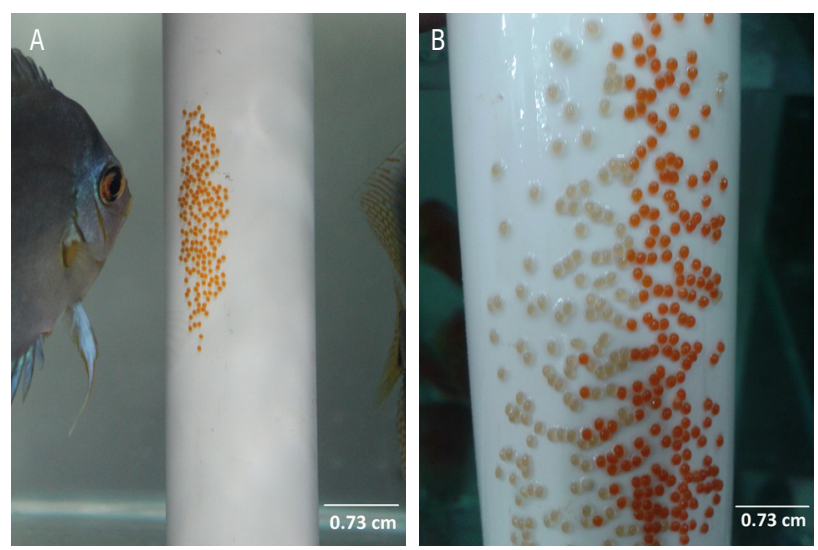

Figure 1. Spawning of only one female (A) and synchronous spawning of two females (B) of discus fish, Symphysodon aequifasciatus. This figure is in color in the electronic version. 
compared to individuals that were kept in aquariums with females (Field and Waite 2004).

Seahorses, Hippocampus reidi Ginsburg, 1933 showed a similar behavior to that found in $S$. aequifasciatus females, by forming same-sex couples of males and females and performing characteristic courtship movements (Silveira 2009). In Hippocampus reidi, however, the homosexual behavior was induced by the presence of only same-sex individuals in the aquarium, while in $S$. aequifasciatus samesex couple formation occurred in the presence of both sexes.

The motivations that lead individuals of the same sex to form couples are still unknown and more experimental behavioural studies are needed to understand the causes of homosexual behavior in these species, since the reproductive investment of same-sex couples does not produce offspring. Our observations contributed to further the knowledge about the reproductive dynamics of $S$. aequifasciatus and generated usefull information for the breeding management in this species.

\section{REFERENCES}

Altmann, J. 1974. Observational study of behavior: sampling methods. Behavior, 69: 227- 263.

Bailey, N.W.; Zuk, M. 2009. Same-sex sexual behavior and evolution. Trends in Ecology and Evolution, 24: 1-8.
Câmara, M.R. 2004. Biologia Reprodutiva do Ciclídeo Neotropical Ornamental Acará Disco, Symphysodon discus Heckel, 1840 (Osteichthyes: Perciformes: Cichlidae) Doctoral thesis, Universidade Federal de São Carlos, São Carlos, São Paulo. 147p.

Dias, R. L.; Chellappa, S. 2003. Desenvolvimento gonadal do ciclídeo ornamental acará bandeira, Pterophyllumscalare. In: Urbinati, E.C.; Cyrino, J.E.P. (Ed). Anais do XII Simpósio Brasileiro de Aqüicultura. Aquabio, Jaboticabal, p.135-148.

Field, K.L.; Waite, T.A. 2004. Absence of female conspecifics induces homosexual behaviour in male guppies. Animal Behaviour, 68: 1381-1389.

Mattos, D.C.; Screnci-Ribeiro, R.; Cardoso, L.D.; Vidal Junior, M.V. 2016. Description of the reproductive behavior of Symphysodon aequifasciatus (Cichlidae) in captivity. Acta Amazonica, 46: 433-438 .

Silva, R.M.P.C. da; Esper, M.L.P. 1991. Observaçôes sobre o desenvolvimento citomorfológico dos ovários de tainha, Mugilplatanus (Günther) da Baía de Paranaguá (Brasil). Acta Biologica Paranense, 20: 15-39.

Silveira, R.B.; 2009. Sobre o comportamento sexual do cavalomarinho, Hippocampus reidi Ginsburg, 1933 (Pisces: Synganthidae) em laboratório. Biociências, 17: 20-32.

Wattley, J. 1991. Discus for the perfectionist. 1st ed. T.F.H Publications, Neptune City, 128p.

Received: $12 / 07 / 2016$

Accepted: 06/03/2017 
